\title{
The Importance of Good Governance on Achieving Sustainable Development Case Study: Yemen
}

\section{AbdulGhani Gaghman}

The Bucharest University for Economic Studies, George Cosbuc 16-18A, Tunari, Ilfov, 077180

\section{Abstract}

Governance has become one of the most important concepts in developing countries. Consequently, many countries are trying to pursue good governance and adoption according to the established concept of governance in order to achieve the desired sustainable economic growth and development. Yemeni economy has been in deep recession due to Saudi alliance war since March 2015. Once the war stops, restructuring economy required a new development approach with firm and well define good governance principles aiming to achieve Sustainable Development goals.

Yemen as one of the least developing country, not all of its efforts to move ahead

Corresponding Author: AbdulGhani Gaghman abdulghanigaghman@ stud.ase.ro

Received: 17 November 2019 Accepted: 6 January 2019 Published: 12 January 2020

Publishing services provided by Knowledge E

(c) AbdulGhani Gaghman. This article is distributed under the terms of the

Attribution License, which permits unrestricted use and redistribution provided that the original author and source are credited.

Selection and Peer-review under the responsibility of the EBEEC Conference Committee. economically have been successful. There is more than one reason for its failure to achieve sustainable economic development, but one is absence of good governance. International organizations, donors, and researchers have prescribed good governance as a solution to persistent development problems. This paper is an attempt to enrich this subject, at least in part, by examining the value of adopting good governance on achieving sustainable development.

Based on research findings and learning from other countries experience, development progress and challenges, general framework to implement good governance has been recommended to be consider in the future national development agenda to tolerate achieving sustainable development. Building human capacity is one of the key requirements needed to make a qualitative shift towards sustainable development. The current situation of sustainable development and governance in Yemen as a case study has been reviewed in an explanatory methodologies using regional statistics and global database such as UN organizations, World Bank, HDI, SDGs and Governance indicators to examine the progress made over the last decade. Paper recommended practical steps and actions to be taken to help the official government to reform the current institutional arrangements at the regional as well as national levels, such as adopt governance principles, long term planning, and establishing "High Councils for good governance" to ensure integrated policy formulation, adequate cooperation and coordination among different government entities, and between the government and non-state stakeholders. These recommendation and result have been presented to the Yemeni official government and economic institutions aiming to be integrated in the reform strategies, in particular in the Yemen National Development Strategy (2030).

Based on research findings and learning from other countries experience, development progress and challenges, general framework to implement good governance has been recommended to be consider in the future national development agenda to achieve sustainable development. 
Keywords: Sustainable Development, Good Governance, Economic Reform, Yemen, SDGs

jel CLASSIFICATION codes: O Economic Development, Innovation, Technological Change, and Growth; O1 Economic Development; O2 Development Planning and Policy

\section{Introduction}

The theme of sustainable development over the past years has attracted international attention. The international summits and forums have been held for this purpose, notably the Johannesburg Summit held in South Africa in 2002 [24] and recently at a historic international summit in September 2015. The world leaders adopted the 17 sustainable development goals of the " 2030 Sustainable Development Plan" formally implemented and operational in January 2016 for the next 15 years [25]. Assumptions had been made that, for new universally applicable goals, countries will work to mobilize efforts to eradicate poverty in all its forms, combat inequality and address climate change, while ensuring that all are included. Although sustainable development objectives are not legally binding, governments are expected to take ownership and develop national frameworks to achieve them.

Global governance 'refers to 'government-like' activities in the international system. It is performed by panoply of constantly-changing institutions, including international law, international and regional organisations, and NGOs [12]. Governance has become one of the most important concepts in both developed and developing countries. Consequently, many countries, especially in the developing world, are trying to pursue good governance and adoption according to the established concept of governance in order to achieve the desired sustainable economic growth and development.

The high level of governance is an important issue in any development debate because it is linked to economic growth. Kaufmann and Kraay (2002) argued that governance quality and economic growth are positively related. Based on the worldwide governance indicators (WGI) evaluation from 1996 to 2002, they found that "per capita incomes and the quality of governance are strongly positively correlated across countries" [11]. Moreover, the studies conducted by the World Bank (2018) show the relationship between good governance and high per capita national income [28]. However, even as a measurement of wealth, GDP leaves a lot to be desired. It does not 
consider levels of inequality within a country -- whether it be the gap between the rich and poor or any instances of social or political discrimination. It also does not consider the methods of the creation or accumulation of wealth, such as the detrimental effects of the exploitation of natural resources. In this regard, GDP does not measure a standard of living at all -- it should instead be seen as a measure of economic activity [14]. The adoption of the main standards of transparency and clarity leads to better use of local resources, however there is a gap of studies in the subject of this paper related to Yemen.

Yemen, like other countries in the world, was not immune from resorting to these multifaceted and comprehensive reforms of all sectors. It is living a new system and policies in economic policies and ideas. Developments ideas have been approaches, included resorting to free economic policies by adopting market mechanisms and entering into a market economy. It has become imperative to keep pace with global developments in various social, economic and political fields. This was reflected in the transformations that Yemen experienced, especially after the unification of Yemen in 1990 to the pre-war Arab alliance in March 2015 [31].

The economy, which was already fragile, weakened further as a result of disruption to oil production and other economic activities. Since 2014, the Yemeni economy has been in a deep recession that has only worsened. 2017 GDP contracted to $-5.9 \%$, from 7.7\% in 2010 GDP [30]. Other 2017 key economic indicators include a 13.7\% industrial production growth rate, a 7.425 million people work force, over $25 \%$ unemployment, more than $75 \%$ of the population below the poverty line, $16.5 \%$ of GDP collected through taxes, a $-6.9 \%$ of GDP budget deficit, $135.5 \%$ of GDP in public debt, and a $20 \%$ inflation rate. Additionally, Yemen ranks 168th in the UNDP's Human Development Reports and 178th out 180 countries [22] in Transparency International's 2017 Corruption Perceptions Index with a score of 14/100 [30] (Table 1).

Economic prospects for Yemen in 2018 and beyond will critically depend on rapid improvements of the political and security situation, and ultimately whether an end to the ongoing conflict will allow for rebuilding the economy and social fabric (Table 2). If violence can be contained by late 2018 , GDP is projected to begin to recover in 2019 , with double-digit GDP growth. More reconstruction project and strategic plan in place to reconstrue and develop Yemen which need to consider governance as a requirement for and an outcome of sustainable development policies [29]. 
TABLE 1: Yemen Key Economic Indicators (Source: [30]).

\begin{tabular}{|c|c|c|c|c|}
\hline Indicator & 1990 & 2000 & 2010 & 2017 \\
\hline Population, total (millions) & 12.06 & 17.87 & 23.61 & 28.25 \\
\hline Population growth (anmual \%) & 4.5 & 2.8 & 2.7 & 2.4 \\
\hline Poverty headcount ratio at $\$ 1.90$ a day (2011 PPP) (\% of population) & -. & 7.4 & -- & 118.8 \\
\hline GNI, Atlas method (current US\$) (billions) & 6.62 & 7.42 & 27.87 & 34.42 \\
\hline GNI per capita, Atlas method (current US\$) & 500 & 420 & 1,18 & 1,25 \\
\hline \multicolumn{5}{|l|}{ People } \\
\hline Life expectancy at birth, total (years) & 58 & 60 & 64 & 65 \\
\hline Fertility rate, total (births per woman) & 8.6 & 6.3 & 4.7 & 4.0 \\
\hline \multicolumn{5}{|l|}{ Economy } \\
\hline GDP (current US\$) (billions) & 5.65 & 9.65 & 30.91 & 31.27 \\
\hline GDP growth (annual \%) & 6.3 & 6.2 & 7.7 & -5.9 \\
\hline Inflation, GDP deflator (anmual \%) & 12.0 & 23.6 & 23.6 & 19.7 \\
\hline Agriculture, forestry, and fishing, value added (\% of GDP) & 24 & 14 & 8 & 6 \\
\hline Industry (including construction), value added (\% of GDP) & 34 & 46 & 44 & 42 \\
\hline \multicolumn{5}{|l|}{ States and markets } \\
\hline Time required to start a business (days) & -- & 73 & 13 & 41 \\
\hline Domestic credit provided by financial sector (\% of GDP) & 51.8 & 5.3 & 19.5 & .. \\
\hline Tax revenue ( $\%$ of GDP) & -- & -- & -- & .- \\
\hline Military expenditure (\% of GDP) & 6.2 & 4.4 & 4.7 & 5.0 \\
\hline High-technology exports (\% of manufactured exports) & -- & 0 & $\mathbf{0}$ & 5 \\
\hline Statistical Capacity score (Overall average) & .- & -. & 49 & 44 \\
\hline
\end{tabular}

\section{Relevance of the Study}

Yemen is a low-income country that faces difficult long-term challenges to stabilizing and growing its economy, and the current conflict has only exacerbated those issues. Prior to the escalation of conflict in 2015, development in Yemen was strained. A country of 30 million people, Yemen ranked: (a) 153rd on the Human Development Index (HDI); (b) 138th in extreme poverty; (c) 147th in life expectancy; (d) 172nd in educational attainment; and, (e) was in the World Bank low-middle income category. Projections suggest that Yemen would not have achieved any of the Sustainable Development Goals (SDGs [18]) by 2030 even in the absence of conflict [19]. The ongoing war has halted Yemen's exports, pressured the currency's exchange rate, accelerated inflation, severely limited food and fuel imports, and caused widespread damage to infrastructure. At least $82 \%$ of the population is in need of humanitarian assistance. Prior to the start of the conflict in 2014, Yemen was highly dependent on declining oil resources for revenue. Oil and gas earnings accounted for roughly $25 \%$ of GDP and $65 \%$ of government revenue [31]. 
TABLE 2: Macro Poverty Outlook Indicators- (Source: [30]).

\begin{tabular}{|c|c|c|c|c|c|c|}
\hline & 2015 & 2016 & 2017 e & $2018 \mathrm{f}$ & 2019 f & $2020 \mathrm{f}$ \\
\hline Real GDP growth, at constant market prices & -37.1 & -34.3 & -13.8 & -0.5 & 17.9 & 16.3 \\
\hline Private Consumption & -29.3 & -27.5 & -8.9 & -0.8 & 6.6 & 3.4 \\
\hline Government Consumption & -26.0 & -23.0 & -37.1 & 26.1 & 0.7 & 12.7 \\
\hline Gross Fixed Capital Investment & -85.2 & -39.6 & 9.3 & 220.2 & 33.8 & 15.2 \\
\hline Exports, Goods and Services & -68.1 & -78.5 & 43.2 & 196.8 & 81.4 & 55.4 \\
\hline Imports, Goods and Services & -45.1 & -20.5 & -1.1 & 55.9 & 12.1 & 10.1 \\
\hline Real GDP growth, at constant factor prices & -37.6 & -35.0 & -13.6 & 0.5 & 19.4 & 17.8 \\
\hline Agriculture & -34.9 & -31.4 & -15.0 & -5.0 & 11.0 & 9.0 \\
\hline Industry & -43.1 & -43.4 & -9.6 & 1.0 & 22.1 & 25.8 \\
\hline Services & -34.9 & -31.4 & -15.0 & 3.3 & 22.2 & 17.3 \\
\hline Inflation (Consumer Price Index) & 61.4 & -20.3 & 4.9 & 23.0 & 20.0 & 7.5 \\
\hline Current Account Balance (\% of GDP) & -6.5 & -5.2 & -1.0 & -6.5 & -3.8 & 0.3 \\
\hline Fiscal Balance (\% of GDP) & -11.5 & -16.5 & -7.6 & -14.0 & -8.6 & -2.7 \\
\hline Debt (\% of GDP) & 72.7 & 128.0 & 141.8 & 130.9 & 98.5 & 84.7 \\
\hline Primary Balance ( $\%$ of GDP) & -3.4 & -7.3 & -7.2 & -7.7 & -1.9 & 1.7 \\
\hline International poverty rate (\$1.9 in 2011 PPP) ${ }^{\mathrm{a}, \mathrm{b}}$ & 50.0 & 76.3 & 82.9 & 83.9 & 78.9 & 73.6 \\
\hline Lower middle-income poverty rate (\$3.2 in $2011 \mathrm{PPP})^{\mathrm{a}, \mathrm{b}}$ & 79.7 & 92.2 & 94.7 & 95.1 & 92.9 & 90.5 \\
\hline Upper middle-income poverty rate ( $\$ 5.5$ in $2011 \mathrm{PPP})^{\mathrm{a}, \mathrm{b}}$ & 93.5 & 98.2 & 99.0 & 99.1 & 98.4 & 97.8 \\
\hline
\end{tabular}

Yemen as a developing country, not all of its efforts to move economically ahead have been successful. There is more than one reason for its failure to achieve sustainable economic development, but one is absence of good governance. International organizations, donors, and researchers have prescribed good governance as a solution to persistent development problems. However, in Yemen specifically, no single study on this subject has yet been carried out according to the researcher knowledge. This proposal is an attempt to fill this gap, at least in part, by examining the impact of governance on sustainable economic development.

Despite the efforts made by the Arab countries, including Yemen, economic development to be achieve through the promotion of good governance, openness and integration with the global economy. In order to achieve comprehensive development, a series of effective measures must be taken in order to achieve the demands of democracy and transparency, sustainable development and its goals [1].

Based on the above, the main problem of research can be formulated in the following:

What is the importance of implementing Governance principles on achieving the Sustainable Development in Yemen?

Research hypothesis is "There is a positive impact of good governance concept on sustainable development" To facilitate and highlight the problem this paper aims to answer the following questions:

1. What is the status of sustainable development and Governance in Yemen? 
2. Assess the implications of good governance adoption on the dimensions of sustainable development?

3. What are the major obstacles and challenges to sustainable development and good governance in Yemen?

\section{Sustainable Development concept}

A definition of sustainable development (SD) can be "to meet the basic needs of people today without ruining the chances of future generations to do the same". Sustainable development means different things to different people/groups. The most widely held definition is that of the Brundtland Commission Report [3], which stated we must "meet the needs of the present without compromising the ability of future generations to meet their own needs". In other words, when people make decisions about how to use the Earth's resources such as forests, water, minerals, gems, wildlife, etc., they must take into account not only how much of these resources they are using, what processes they used to get these resources, and who has access to these resources. Are enough resources going to be left for your grandchildren to use and will the environment be left as you know it today.

Although the concept of sustainable development may be newly understood, it does not represent a pure modern, but it has existed since ancient times, as the reality of the emergence of this concept is linked to the production systems and consumption models used and resulting in obvious damage to scarce resources and biological and cultural diversity. The cost of neglecting the environment and irrational resources exploitation is so high for the current generation and more for the future generations.

In the next table the historical evolution explicit of this concept through several world leader summits and conferences [19].

In conclusion, sustainable development is a development that meets the needs of the present without compromising the ability of future generations to meet their own needs. It contains within it two key concepts:

- The concept of 'needs', in particular the essential needs of the world's poor, to which overriding priority should be given; and

- The idea of limitations imposed by the state of technology and social organization on the environment's ability to meet present and future needs.

Thus, the goals of economic and social development must be defined in terms of sustainability in all countries developed or developing, market-oriented or centrally 
TABLE 3: The Historical Evolution Explicit of SD Concept Through Several World Leader Summits and Conferences since 2000 (source from [20], collected by the Author).

\begin{tabular}{|c|c|c|}
\hline Event Name & Purpose or Agenda & Key Outcomes \\
\hline The Millennium Declaration (2000) & $\begin{array}{l}\text { The Declaration committed nations to a new } \\
\text { global partnership to reduce extreme poverty and } \\
\text { set cut a series of eight time-bound targets - with } \\
\text { a deadline of } 2015 \text { - that have become known as } \\
\text { the Millemnium Development Goals (MDGs). }\end{array}$ & $\begin{array}{l}\text { UN Millemium } \\
\text { Declaration (MDG, 2015) }\end{array}$ \\
\hline $\begin{array}{l}\text { Word Summit on Sustainable } \\
\text { Development - Johannesburg (2002) }\end{array}$ & $\begin{array}{l}\text { The Conference reviewed the challenges and } \\
\text { opportumities that could affect the prospects for } \\
\text { achieving sustainable development and the } \\
\text { progress made in the implementation of Agenda } \\
\text { 21. }\end{array}$ & $\begin{array}{l}\text { Johannesburg Summit } \\
\text { (Plan of actions) }\end{array}$ \\
\hline $\begin{array}{l}\text { Addis Ababa Action Agenda of The } \\
\text { Third International Conference on } \\
\text { Financing for Development }\end{array}$ & $\begin{array}{l}\text { The meeting agreed to work to finance and } \\
\text { create an enabling ervironment at all levels for } \\
\text { sustainable development, in a spinit of } \\
\text { partmership and solidarity at the global level. }\end{array}$ & $\begin{array}{l}\text { Addis Ababa Action } \\
\text { Agenda, } 2015\end{array}$ \\
\hline $\begin{array}{l}\text { Transforming cour world: the } 2030 \\
\text { Agenda for Sustainable Development. }\end{array}$ & $\begin{array}{l}\text { This Agenda is a plan of action for people, } \\
\text { planet and prosperity. including its } 17 \\
\text { Sustainable Development Goals (SDGs) and } 169 \\
\text { targets was adopted on } 25 \text { September } 2015 \text {. }\end{array}$ & $\begin{array}{l}\text { The Global Goals } 2030 \\
\text { (UN, 2016) }\end{array}$ \\
\hline $\begin{array}{l}\text { Our Ocean, Our Future: Call for } \\
\text { Action (2017) }\end{array}$ & $\begin{array}{l}\text { Support the implementation of SDGs \#Goal_14 } \\
\text { of the SDGs } 2030 \text { to affim our strong } \\
\text { commitment to conserve and sustainably use our } \\
\text { oceans, seas and marine rescurces for sustainable } \\
\text { development }\end{array}$ & \\
\hline
\end{tabular}

planned. Interpretations will vary but must share certain general features and must flow from a consensus on the basic concept of sustainable development and on a broad strategic framework for achieving it.

The UNDP indices are amongst the most commonly cited development indicators, and the most widely used are the Human Development Index (HDI), the Gender Development Index (GDI) and the Human Poverty Index (HPI) (Table 4). The Human Development Index (HDI) implemented by UNDP is a summary measure of average achievement in key dimensions of human development: a long and healthy life, being knowledgeable and have a decent standard of living. The HDI can also be used to question national policy choices, asking how two countries with the same level of GNI per capita can end up with different human development outcomes. These contrasts can stimulate debate about government policy priorities. [7].

Of course, the HDI has its limitations. It omits several factors that can have a significant influence on quality of life, such as environmental degradation. Industrial pollution and deforestation, for example, can lead to complex health problems (e.g. Iymphatic filariasis) or mental health conditions that do not necessarily have an impact on mortality rates, but which can severely impair one's mobility or quality of living [14]. 
TABLE 4: Human Development Indicators (Source: [8]).

Human Development Index (HDI)

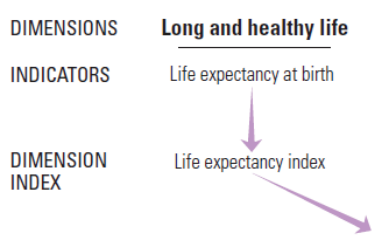

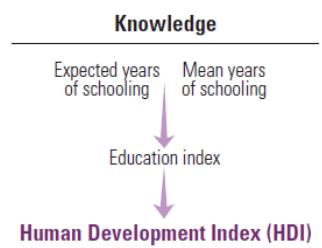

A decent standard of living

GNI per capita (PPP \$)

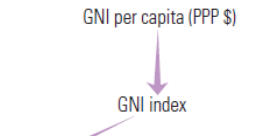

UNSDSN plotted the HDI vS SDGs and show a linear relationship between both indices, however in this research both indices have been used [26] (Figure 1).

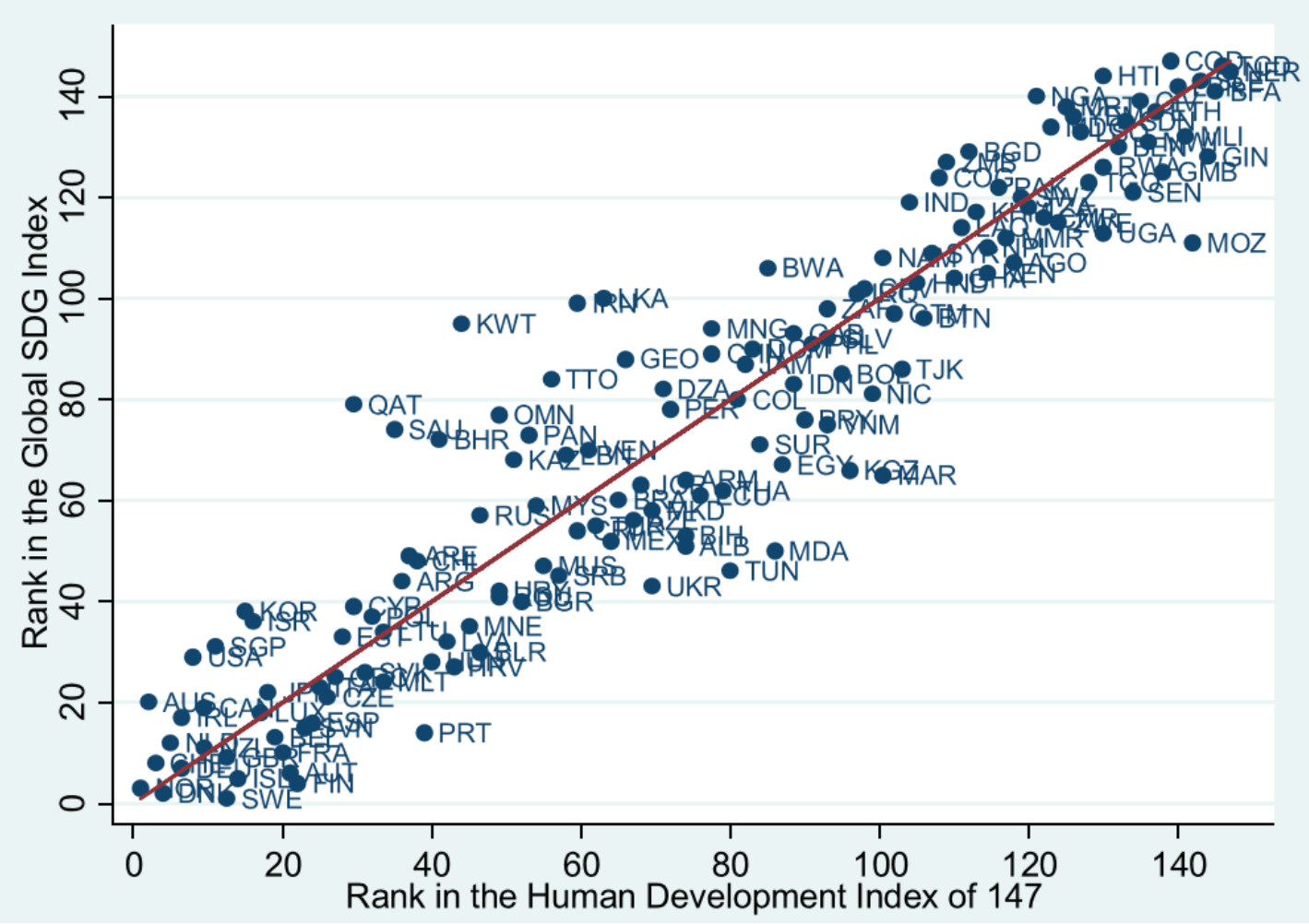

Figure 1: Comparison of rankings by Global SDG Index and by Human Development Index (Source [26]).

\section{Governance Concept}

Given that the term "governance" means different things to different people. Among the many definitions of "governance" that exist, the one that appears the most appropriate from the viewpoint of the UNDP is "the exercise of economic, political and administrative authority to manage a country's affairs at all levels. It comprises mechanisms, processes and institutions through which citizens and groups articulate their interests, exercise their legal rights, meet their obligations and mediate their differences" [19]. 
According to the World Bank, governance is "the manner in which power is exercised in the management of a country's economic and social resources for development."[9]. On this meaning, the concept of governance is concerned directly with the management of the development process, involving both the public and the private sectors. It encompasses the functioning and capability of the public sector, as well as the rules and institutions that create the framework for the conduct of both public and private business, including accountability for economic and financial performance, and regulatory frameworks relating to companies, corporations, and partnerships. In broad terms, then, governance is about the institutional environment in which citizens interact among themselves and with government agencies/officials [9]. Malito has summarized the governance definitions introduced by several organization in (Table 5) [15].

TABLE 5: Definitions of Governance (Source: [15]).

\begin{tabular}{|c|c|c|}
\hline Institutions & Definitions & Characteristics \\
\hline $\mathbf{E C}$ & $\begin{array}{l}\text { 'Govemance represents both the rules, process, and behaviour that affect the } \\
\text { way in which powers are exercised at the European level, particularly as } \\
\text { regard to openness, participation, accountability, effectiveness and } \\
\text { coherence' (European Commission, 2001). }\end{array}$ & \\
\hline WB & $\begin{array}{l}\text { Govemance concems 'the traditions and institutions by which authority in a } \\
\text { country is exercised This includes (a) the process by which govemments are } \\
\text { selected, monitored and replaced; (b) the capacity of the govemment to } \\
\text { effectively fomulate and implement sound policies; and (c) the respect of } \\
\text { citizens and the state for the institutions that govem economic and social } \\
\text { interactions among them' (Kaufmann, Kraay, \& Mastruzzi, 2011, p. 222). }\end{array}$ & $\begin{array}{l}\text { Input (Process and } \\
\text { Structure) }\end{array}$ \\
\hline OECD & $\begin{array}{l}\text { 'Govemance is the exercise of political, economic and administrative } \\
\text { authority necessary to manage a nation's affairs' (OECD, 2014). }\end{array}$ & Input (Process) \\
\hline UN & $\begin{array}{l}\text { In the community of nations, govemance is considered "good" and } \\
\text { "democratic" to the degree in which a country's institutions and processes are } \\
\text { transparent' (United Nations, 2014). }\end{array}$ & $\begin{array}{l}\text { Input (as Quality of } \\
\text { institutions and } \\
\text { Process) }\end{array}$ \\
\hline
\end{tabular}

Theoretically, governance is generally understood as a form of rule without formal government [16], i.e. as a set of regulatory mechanisms implemented without the classical tools of state regulation. However, the literature does not agree on whether governance is a process or a structure, neither whether it should be operationalised through input nor output indicators.

In a nutshell, good governance refers to the public administration process that maximizes public interest. One of its essential features is that it is a kind of collaborative management of public life performed by both the State and the citizens and a new relationship between political State and civil society, as well as the optimum state of the two. Keping (2018) summarize all the perspectives on good governance and its impact on sustainable development in the following six essentials [13]: 
1. Legitimacy It refers to the state or quality that social order and authority are voluntarily recognized and obeyed. The higher the degree of legitimacy is, the higher the level of good governance will be. The principal approach to achieving and improving legitimacy is to maximize the consensus and political identity shared by citizens.

2. Transparency It refers to the publicity of political information. All citizens are entitled to the information on State policies that are related to their own interests, including legislative activities, policy-making, legal provisions, policy enforcement, administrative budget, public expenditure and other relevant political information. The higher the degree of transparency is, the higher the level of good governance will be.

3. Accountability means holding every person accountable for his or her own behavior. In public administration, it refers in particular to the duties related to a certain position or institution and its corresponding obligations. Accountability means that administrators and administrative bodies must fulfill the functions and obligations of the positions they hold. If they fail to fulfill their bounden functions or duties, or if they do so in an inappropriate manner, their conduct constitutes dereliction of duty or lack of accountability.

4. Rule of law Essentially, rule of law means that law is the supreme principle in public political administration that should be observed by all government officials and citizens, who should be all equal before the law. Rule of law is a basic requirement of good governance, which would be impossible without a sound legal system, due respect for the law or a social order based on the law.

5. Responsiveness is closely associated with the aforementioned concept of accountability. In a sense, it is an extension of accountability. Essentially, it means that public administrators and administrative bodies must respond to the demands of citizens in a timely and responsible manner, and that it is forbidden to make delays without cause or leave any issue unresolved without response. The greater the level of responsiveness is, the higher the level of good governance will be.

6. Effectiveness It mainly refers to management efficiency. It has two essential meanings: rational administrative structure, scientifically designed administrative procedures and flexible administrative activities; and minimized administrative costs. The higher the level of good governance is, the higher the effectiveness of administration will be. 
In this research, data obtained from World Governance Index [27] and Bertelsmann Stiftung's Transformation Index [4] to fulfil the research objectives.

\section{Research Methodology}

Based on the previous objectives, Case Study Methodology has been used to capture the complexity of our single case, aiming to give interpretations and proof of hypotheses. Yemen sustainable economic development and governance is selected as a case study in virtue of being somehow, unique and extreme (the most least developed county in the Arab world) [29], of which has also an intrinsic interest aiming to understand the reason behind its critical economic situation and poor governance, however it has wide spectrum of natural resources and need to plan sustainability for the future.

Explicative research strategy used in this research, of which describe the current situation and history of the case, but simultaneously take account of the context, and so encompass many variables and qualities (i.e. HDI, SDGs, Governance) with focus on contemporary events (i.e. sustainable development) [10].

Several tool and technique used to fulfill the objectives, starting with literature review, descriptive approach, but cannot be limited to the theoretical side. Moreover, present and analysis related economic facts using primary data obtained from thrusted international statistical database as well as official national data issued by Yemeni Central Bureau of Statistics.

\section{Findings}

Current situation of sustainable development in Yemen has been reviewed using national and global database and statistics such as HDI and SDGs to examine the progress made over the last decade, similarly governance indicators has been derived from WGI and BTI. One of the difficulties is a shortcoming of significant data in national report in regard of SDGs and Governance indices.

Therefore, the official data were not used directly from national statistical agencies due to problems in comparability (different method used to calculate the indicators), quality, and availability of time series. 


\subsection{Yemen's HDI value and rank}

Yemen's HDI value for 2017 is $0.452---$ which put the country in the low human development category--- positioning it at 178 out of 189 countries and territories. Between 1990 and 2017, Yemen's HDI value increased from 0.399 to 0.452 , an increase of 13.3 percent. Table 6 reviews Yemen's progress in each of the HDI indicators. Between 1990 and 2017, Yemen's life expectancy at birth increased by 7.3 years, mean years of schooling increased by 2.7 years and expected years of schooling increased by 1.5 years. Yemen's GNI per capita decreased by about 54.5 percent between 1990 and 2017 (Figure 2) [7].

TABLE 6: Yemen's HDI trends based on consistent time series data and new goalposts (Source: [7]).

\begin{tabular}{|cccccc|}
\hline Year & $\begin{array}{c}\text { Life expectancy } \\
\text { at birth }\end{array}$ & $\begin{array}{c}\text { Expected years } \\
\text { of schooling }\end{array}$ & $\begin{array}{c}\text { Mean years of } \\
\text { schooling }\end{array}$ & $\begin{array}{c}\text { GNI per capita } \\
\text { (2011 PPP) }\end{array}$ & HDI value \\
\hline 1990 & 57.9 & 7.5 & 0.3 & 2,726 & 0.399 \\
1995 & 59.3 & 7.6 & 0.7 & 2,891 & 0.415 \\
2000 & 60.4 & 7.9 & 1.2 & 3,583 & 0.443 \\
2005 & 61.9 & 8.7 & 1.9 & 3,741 & 0.474 \\
2010 & 63.5 & 8.6 & 2.6 & 4,227 & 0.498 \\
2015 & 64.7 & 9.0 & 3.0 & 2,229 & 0.483 \\
2016 & 65.0 & 9.0 & 3.0 & 1,480 & 0.462 \\
2017 & 65.2 & 9.0 & 3.0 & 1,239 & 0.452 \\
\hline
\end{tabular}

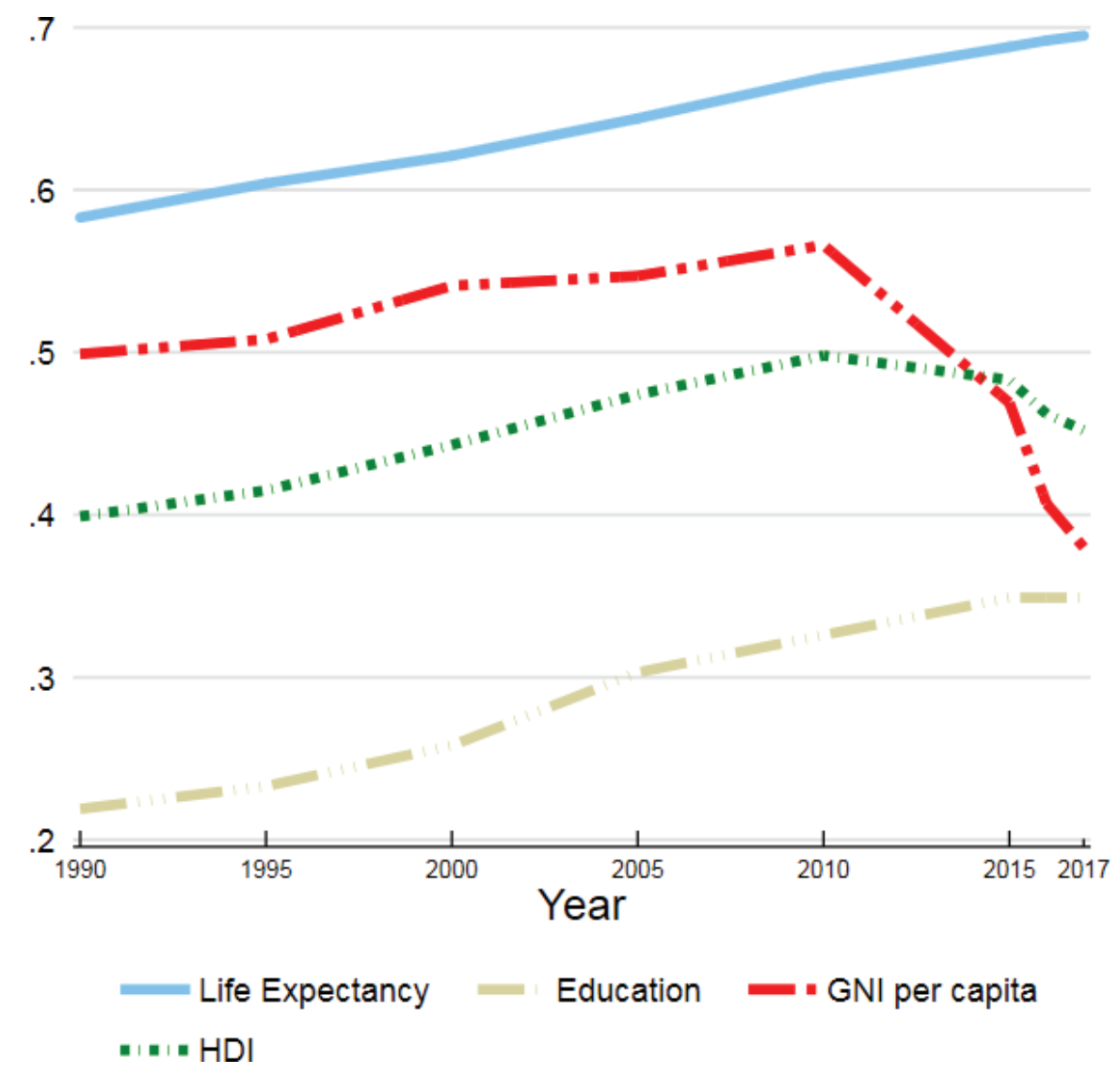

Figure 2: Trends in Yemen's HDI Component Indices 1990-2017 (Source: [7]). 
The human development progress, as measured by the HDI, can usefully be compared to other countries. For instance, during the period between 1990 and 2017 Yemen, Morocco and Sudan experienced different degrees of progress toward increasing their HDIs (see Figure 3).

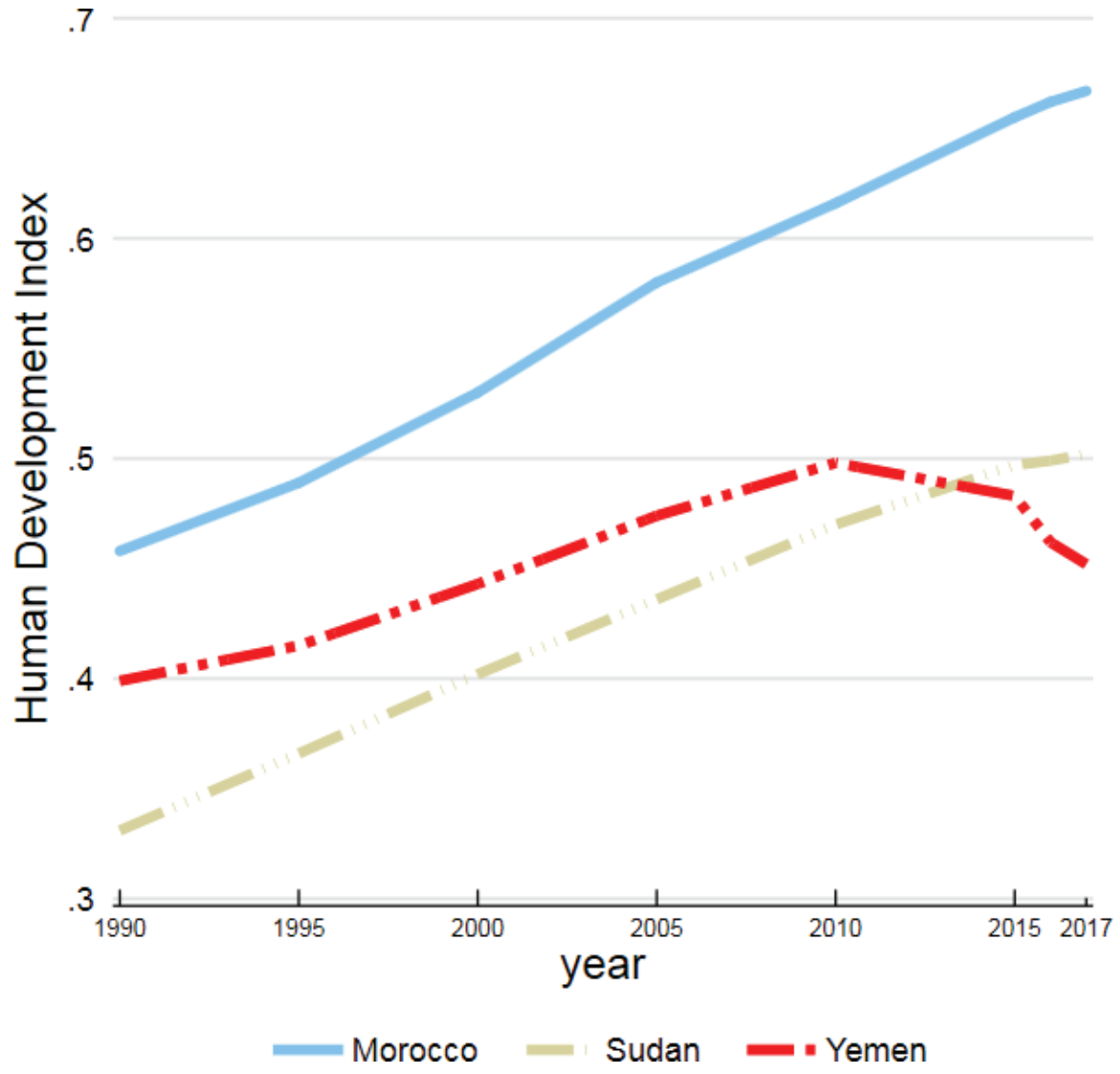

Figure 3: HDI trends for Yemen, Morocco and Sudan, 1990-2017 (Source [8], 2018 p 3).

From Arab States, countries which are close to Yemen in 2017 HDI rank and to some extent in population size are Djibouti and Sudan, which have HDIs ranked 172 and 167 respectively [7] (see Table 7).

TABLE 7: Yemen's HDI and component indicators for 2017 relative to selected countries and groups (Source [7]).

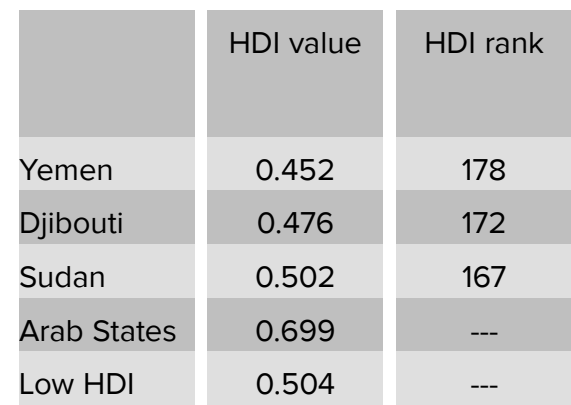

\begin{tabular}{|c|}
$\begin{array}{c}\text { Life } \\
\text { expectancy } \\
\text { at birth }\end{array}$ \\
65.2 \\
62.6 \\
64.7 \\
71.5 \\
\hline 60.8 \\
\hline
\end{tabular}

\begin{tabular}{|c|}
\hline $\begin{array}{l}\text { Expected } \\
\text { years of } \\
\text { schooling }\end{array}$ \\
\hline 9.0 \\
\hline 6.2 \\
\hline 7.4 \\
\hline 11.9 \\
\hline 9.4 \\
\hline
\end{tabular}

\begin{tabular}{c} 
GNI per \\
capita (PPP \\
US\$) \\
\hline 1,239 \\
\hline 3,392 \\
\hline 4,119 \\
\hline 15,837 \\
\hline 2,521 \\
\hline
\end{tabular}




\subsection{Sustainable development goals indicators}

Implementation of sustainable development goals in Yemen and other Arab developing countries is a challenging endeavor due to the multiple goals and their wide-ranging and interrelated targets [23]. Based on the SDGs indicators database [18], Yemen score only 45 out of 85 , which consider in the lower side of SDG score or more challenges remain (Table 8).

TABLE 8: Yemen's SDGs index score for 2018 relative to selected countries (Source: SDG index, 2018).

\begin{tabular}{|c|c|c|c|c|c|}
\hline Countries & $\begin{array}{c}\text { SDG } \\
\text { Global } \\
\text { rank }\end{array}$ & & Global index score & $\begin{array}{l}\text { Regional } \\
\text { avg. score }\end{array}$ & GDP \\
\hline Yemen & 152 & 45.7 & - $26.4 \%$ than region average & 62.1 & $\$ 2,325.1$ \\
\hline Sudan & 143 & 49.6 & $-6.1 \%$ than region av erage & 52.8 & $\$ 4,386.4$ \\
\hline Morocco & 77 & 663 & $+6.8 \%$ tham region av erage & 62.1 & $\$ 7,285.9$ \\
\hline Algeria & 68 & 67.9 & $+9.3 \%$ thann region arverage & 62.1 & $\$ 13,921.2$ \\
\hline
\end{tabular}

\subsection{Governance indicators}

To ascertain whether governance is 'good', Governance principles based on World Governance Index (Figure 4) [27] and Bertelsmann Stiftung's Transformation Index [4] of which analyzes and evaluates whether and how developing countries and countries in transition are steering social change toward democracy and a market economy, the BTI shows poor governance score in Yemen (1.7 out of 10 and rank 127 out of 129), more worse it is decreasing with time in the last decade 2007 and 2017 (Figure 4).

The relationship between the Governance and Sustainable development can be obviously predicted from the global trend in (Figure 6) where it shows positively strong relationship and in color the Arab region with different HDI score.

Yemen progress in term of Sustainability and Governance comparing to Sudan and Morocco progress during the last decade (2006 to 2018) as shown in (Figure 7) based on [4]. It is obvious that, when governance trend increases (i.e. Morocco \& Algeria) the sustainable development increases and vice versa in case of Yemen and Sudan.

Based on the research findings, improved governance is a must for Yemen for more progress toward SD. Adopting more transparent, accountable, and participatory approaches in the formulation and implementation of policies enhances the confidence of the public in the government and creates a sense of ownership on the part of 


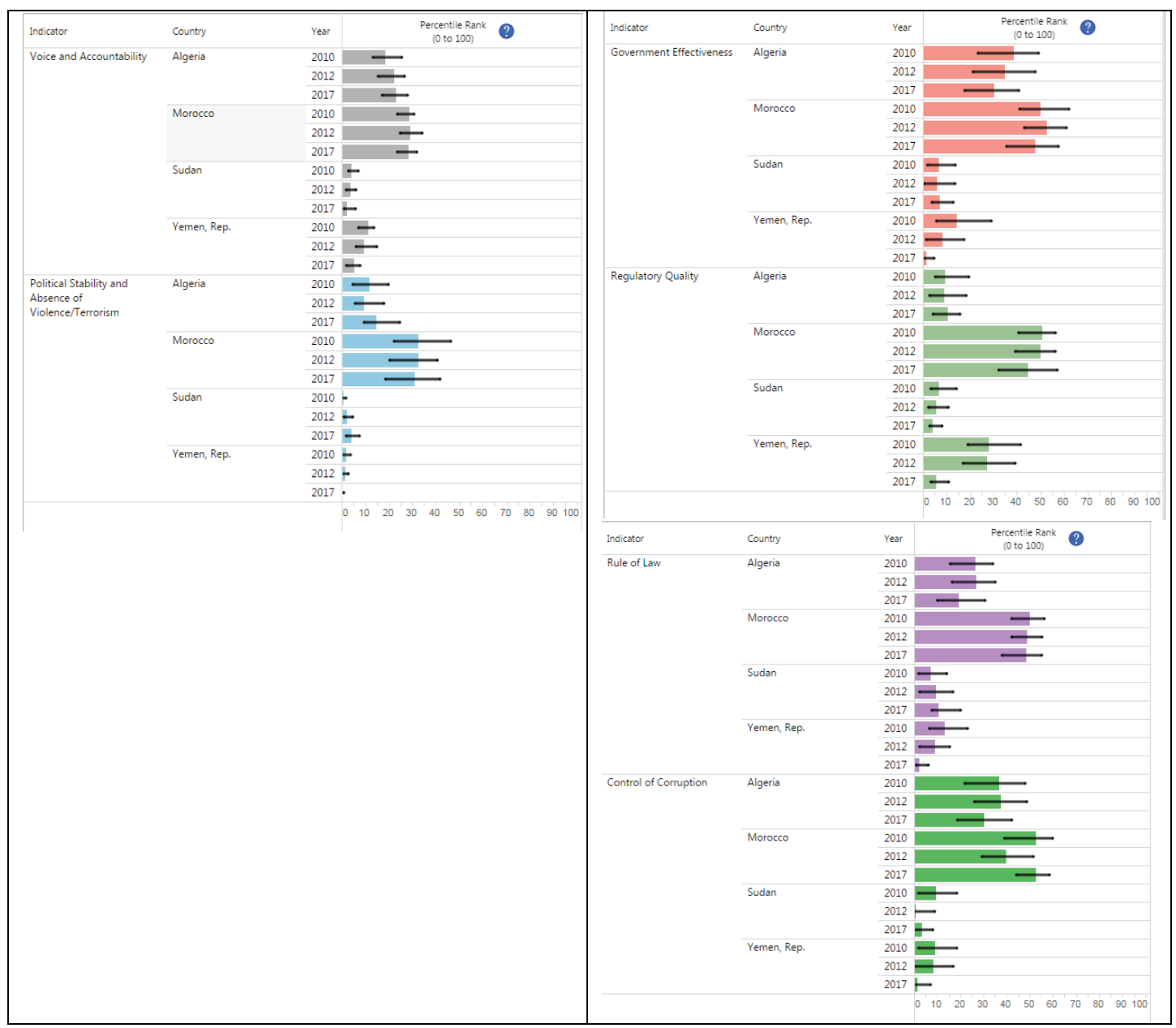

Figure 4: Yemen's World Governance indicators relative to selected countries (Source: [27]).

citizens, thus contributing to a more positive attitude towards the government. This ultimately contributes to increased productivity and a more efficient use of resources. Good governance may therefore be regarded as a requirement for and an outcome of sustainable development policies.

\section{Recommendation}

For development to be sustainable - economically, socially and environmentally -and equitable, a new approach is needed that addresses the political, as well as the technical, aspects of development solutions based on significant improvement in governance principles mainly in Legitimacy, Transparency, Accountability, Rule of law, Responsiveness, Effectiveness.

The strongest endorsement of the importance of governance as a development outcome for the 2030 agenda came from a series of data analysis from national and 
BTI 2018 | Yemen Country Report

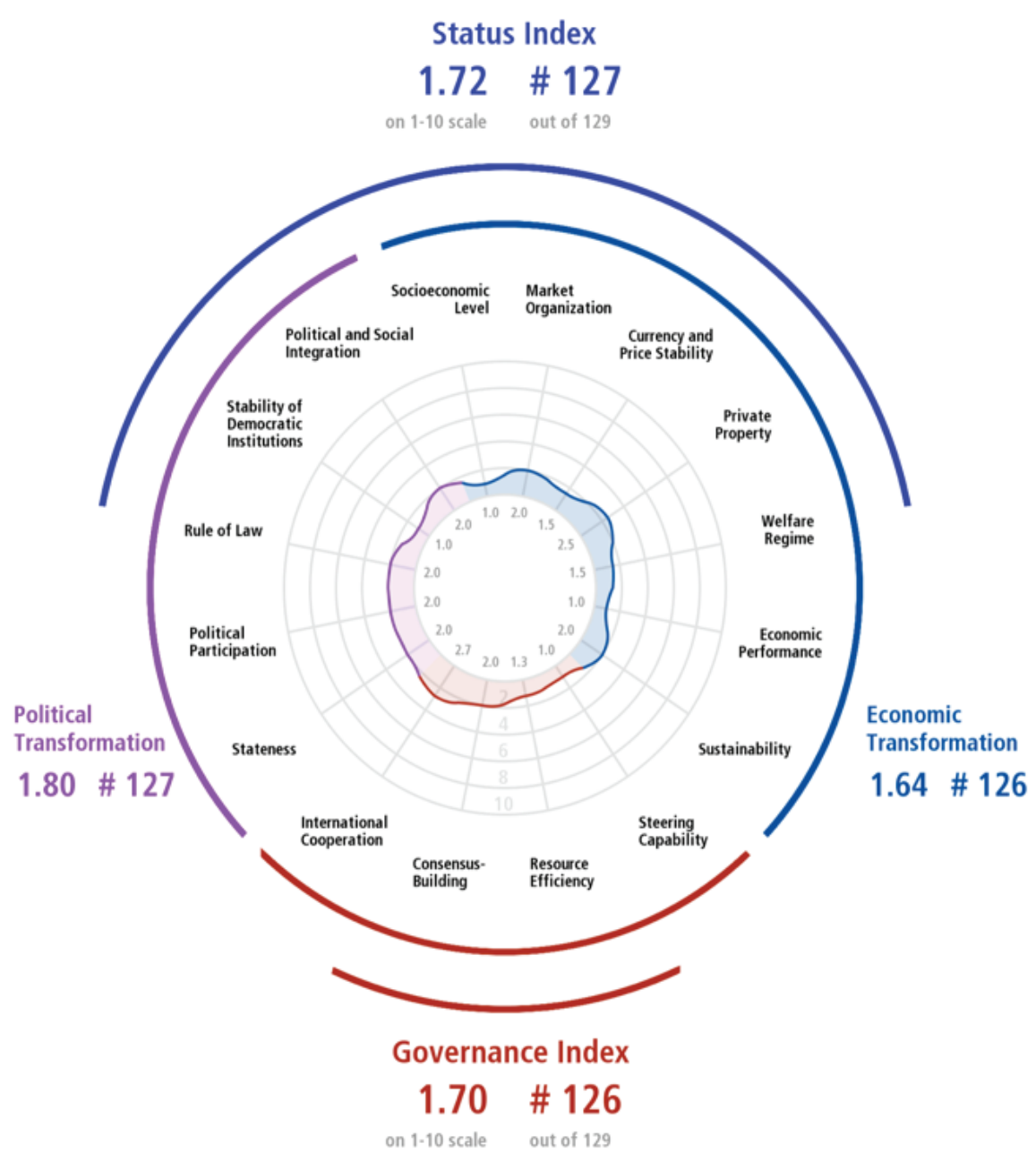

Figure 5: Yemen country Transformation Report (Source: [4]).

international sources. However, in the following section some necessary recommendations are needed for achieving the SDGs in Yemen, covering strategies, policies, planning and governance, those include:

\subsection{Long-term strategies and medium-term plans}

Developing a long-term strategy with a clear vision, action plan, and indicators is an essential requirement for achieving sustainable development. Water, energy and food security continue to be among the main challenges facing Yemen. 
Covernance $\uparrow$ Sustainability $\rightarrow$

2018 | Human Development Index | Middle East and North Africa | Yemen

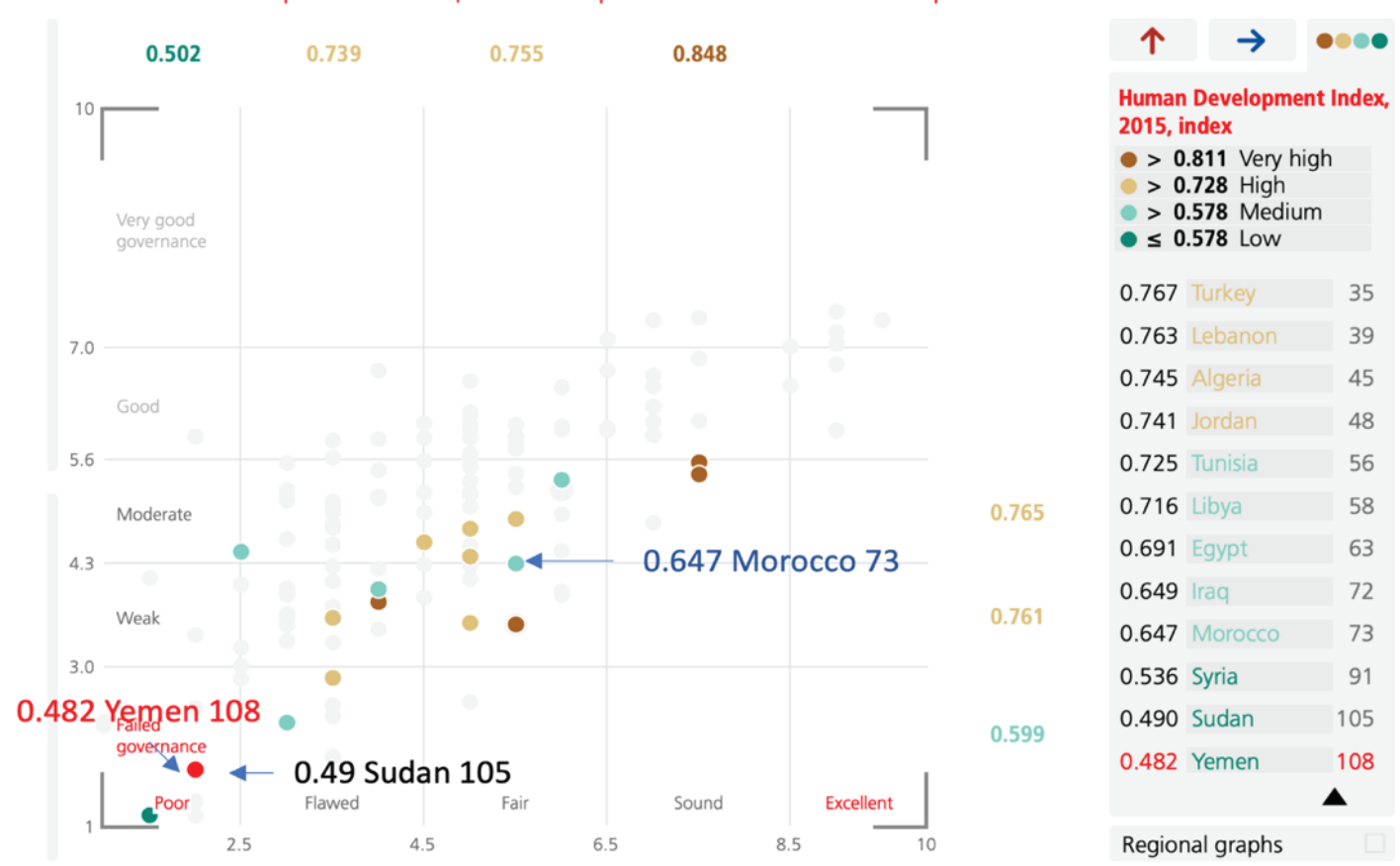

Figure 6: Overall Governance and Sustainability shows positive relationship (Arab region presented in color dots) [4].

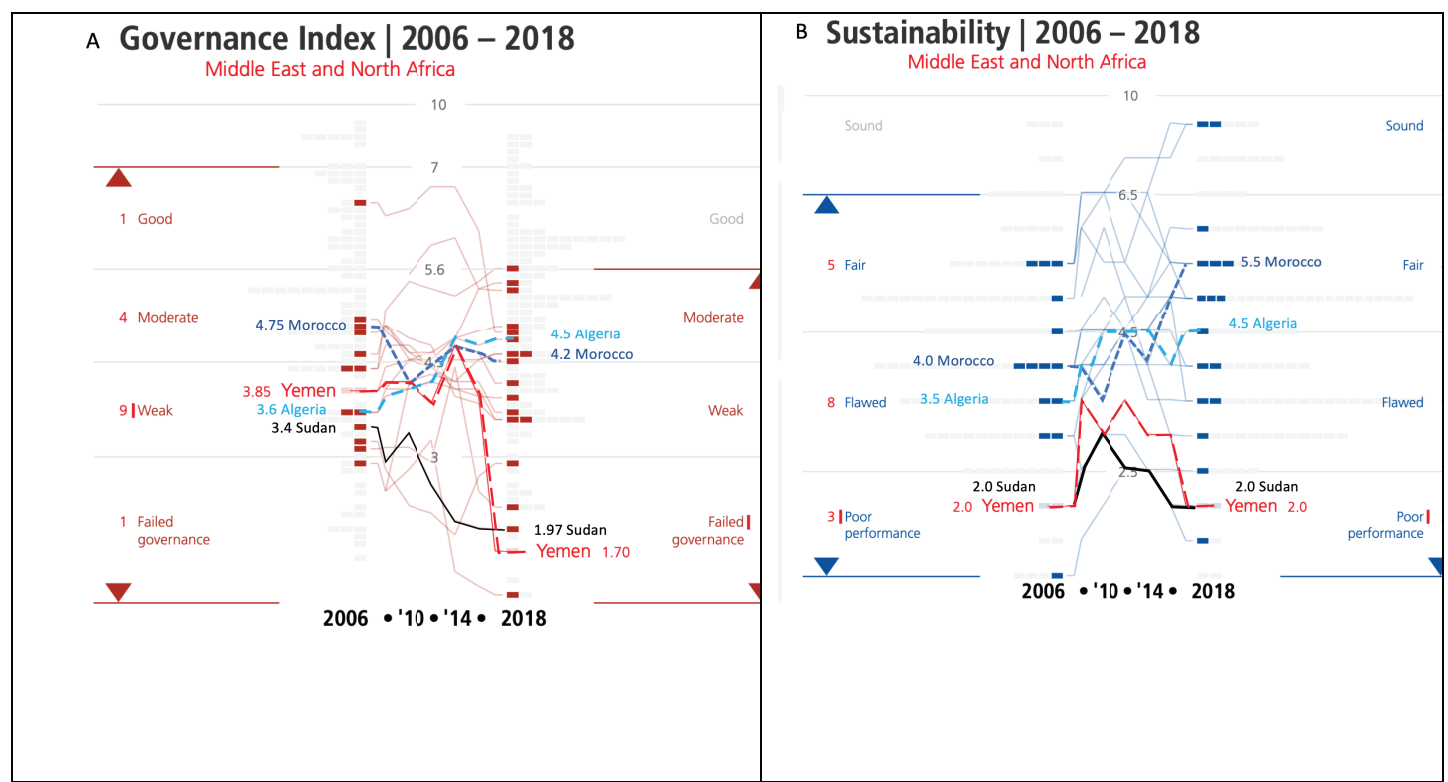

Figure 7: a) Yemen's Governance score over time, b) Sustainability progress over time with relative selected countries [4].

\subsection{High council for good governance}

In order to ensure proper integration of policies and coordination between sectoral policies, policy coherence, as well as monitoring and follow up, it is proposed that a 
High Council for Good Governance attached to either the Head of State or the Prime Minister is established. It is proposed that such an entity includes the membership of all ministries. This body should function in tandem with another entity that represents the private sector, industry, academia and civil society, and minority groups. The main mandate of this institution will be to ensure integrated policy formulation, adequate cooperation and coordination between different government entities, and between the government and all other stakeholders in the country. It will also be responsible for overseeing and assessing the implementation of the proposed overall strategy, and related action plans and programs, suggest corrective or remedial actions as may be required, and ensure adequate communication between the government, the general public, the private sector and civil society.

\subsection{Implement good governance principles}

Good governance represented mostly in national institutions that function in an effective and efficient, transparent and accountable manner are necessary for achieving sustainable development in Yemen. These are lacking in most Arab countries not only in Yemen, thus requiring corrective actions and reform in the existing institutional set-ups of governments. Lack of public participation, transparency and accountability represent some of the main constraints for the development and implementation of strategies, policies, and action plans.

In practice, improving governance requires action in a wide range of areas, not all of which can be addressed at once, and not all can be the subject of a global consensus. The key elements to be consider as following:

\subsubsection{Develop a unified advocacy program of good governance for pub- lic and private sectors in Yemen}

1. Establish good governance guide for all organisation levels of public service

2. Launch a governance code of conduct and training program for public, private sector staff.

3. Time-bound monitoring and evaluation plan to track and assess the efficiency of good governance implementation. 


\subsubsection{Effective, responsive and accountable state institutions}

Improve state capacity (the quality of public administration) [5], or the ability of states to form and implement policy across the whole of their territory, is an essential prerequisite for sustainable development through decentralize government.

\subsubsection{Openness and transparency -- public access to information}

More openness and transparency in all institutions to achieve sustainable development. With more focus on the informed citizens and the private sector as they are better able to engage in developing policy [17]. Transparency in government behaviour sends strong signals to citizens and investors, and evidence shows that the more information a government releases, the greater the investment and subsequent effect on growth [2].

\subsubsection{Addressing corruption and curbing illegal financial flows}

There is a wealth of evidence that corruption in Yemen is a major hindrance to sustainable development, with a disproportionate impact on the poor and marginalized populations. Corruption has negative impact on health and education outcomes, equity, rule of law, and foreign investment. Transparency International, for example, finds that good performance on anti-corruption initiatives and the rule of law is linked with higher youth literacy rates and lower maternal mortality rates [20].

\subsubsection{Justice and the Rule of Law}

The rule of law is a principle of governance and is critical for sustainable development. It has been shown that countries adhering to the rule of law have higher levels of growth and investment through the protection of property rights [21]. Effective rule of law frameworks, together with implementation, is mandatory to prevent and mitigate violent crime, resolve grievances, and protect citizens; all key elements to contain violent conflict. Some studies suggest that a conservative estimate of the economic costs of lost production, due to high levels of crime and violence, ranges from 2 to 3 percent of GDP [28]. 


\subsubsection{Participation in decision-making}

Participation is both a right, and a means to more sustainable development. Required to engaged communities actively in their development processes, project outcomes for better targeted the local needs, better results of which will be more sustainable.

More important recommendations for sustainable development implementation has been thoroughly explained by AFED [1] such as (Integrated Policymaking, Human Resources Development, Invest in Environment, Physical Infrastructure Development and Research and Development) of which need to be discussed in further studies.

\section{Conclusion}

Although the Sustainable Development Goals (SDGs) did not include a goal or targets on governance, the Global Goals Declaration, adopted by the world's leaders in 2016 , recognized the vital link between good governance, development and human rights. It is widely acknowledged that a single model of governance cannot and should not be imposed. Governance varies across contexts and cultures and has evolved in response to a number of socio-cultural and economic factors. Likewise, implementation of the SDGs in Yemen is a challenging endeavor due to the multiple goals and their wideranging and interrelated targets. Financing is a core and an indispensable requirement for the realization of the SDGs.

Governance has become one of the most important concepts in both developed and developing countries. Consequently, many countries in the developing world, are trying to pursue good governance and adoption according to the established concept of governance in order to achieve the desired sustainable economic growth and development.

Based on research findings and learning from other countries experience, development progress and challenges, general framework to implement good governance and sustainable development has been recommended to be consider in the future national development agenda: effective governance institutions and systems that are responsive to public needs deliver essential services and promote inclusive growth, while inclusive political processes ensure that citizens can hold public officials to account. In addition, good governance promotes freedom from violence, fear and crime, and peaceful and secure societies that provide the stability needed for development investments to be sustained. 
key limitation to achieve the SDGs is the huge financing gap of which need to be discuss in detail in future researches, Yemen need to exert concerted efforts to mobilize resources for the implementation of their SDGs. In this respect, both domestic and foreign sources of capital need to be tapped. However, mobilization of domestic resources requires the adoption of implementable policies and measures for fair, equitable, and efficient tax revenue systems.

One of the difficulties is a shortcoming of significant data in national report targets governance and sustainable development indices. Therefore, the official data of countries were not used directly from national statistical agencies, instead relaying on international sources.

\section{References}

[1] AFED (2018). Financing Sustainable Development in Arab Countries. Annual Report of Arab Forum for Environment and Development, Saab, N.,Sadik, A.K., (Ed.); Beirut, Lebanon. Technical Publications.

[2] Andrew. W, (2009). "On the Release of Information by Governments: Causes and Consequences." Journal of Development Economics Vol 89, No. 1pp. 124--38.

[3] Brundtland, G., Khalid, M., Agnelli, S., Al-Athel, S., Chidzero, B., Fadika, L., Hauff, V., Lang, I., Shijun, M., de Botero, M.M. and Singh, M., (1987. Our common future ('brundtland reportl').

[4] BTI, (2018). Bertelsmann Stiftung's Transformation Index. Retrieve from [https://www. bti-project.org/en/home/]

[5] Evans, P., and J. E Rauch. (1999). "Bureaucracy and Growth: A Cross-National Analysis of the Effects of 'Weberian' State Structures on Economic Growth." American Sociological Review Vol. 64, No. 5 pp 748--65.

[6] EU, (2001). European Commission. European Governance: A White Paper. D10-10 Retrieve online from [http://europa.eu/rapid/press-release_DOC-01-10_en.htm]

[7] HDI, (2019). Human Development Index. Retrieved online from http://hdr.undp.org/ en/content/human-development-index-hdi

[8] HDI, (2018). Human Development Indices and Indicators: 2018 Statistical Update. Briefing note for countries on the 2018 Statistical Update

[9] Holzer, M. and Kim, P.J. eds., (2002). Building good governance: Reforms in Seoul. National Center for Public.

[10] Johansson, R., (2007). On Case Study Methodology. Open house international, Vol. 32 No. 3. 
[11] Kaufmann, D., Kraay, A., \&Mastruzzi, M. (2010).The Worldwide Governance Indicators: Methodology and Analytical Issues (World Bank Policy Research Working Paper No. 5430). Washington, DC: The World Bank.

[12] Kemp, R., Parto, S. and Gibson, R.B., (2005). Governance for sustainable development: moving from theory to practice. International Journal of Sustainable Development, Vol. 8 No. 1-2, pp.12-30.

[13] Keping, Y., (2018). Governance and Good Governance: A New Framework for Political Analysis. Fudan Journal of the Humanities and Social Sciences, Vol. 11 No.1, pp.1-8.

[14] Lashmar, H. (2018). United Nations Association -- UK. Retrieved online from https:// www.sustainablegoals.org.uk/human-development-index-better-indicator-success/

[15] Malito, D., (2015). The difficulty of measuring Governance and Stateness. Robert Schuman Centre for Advanced Studies Research Paper No. RSCAS, 38.

[16] Rosenau, J.N., Czempiel, E.O. and Smith, S. eds., (1992). Governance without government: order and change in world politics (20). Cambridge University Press.

[17] Sen, Amartya, and Jean Dreze. (1989). "Hunger and Public Action", Kaufmann, Daniel, and Ana Bellver. (2005). Transparenting Transparency: Initial Empirics and Policy Applications. Rochester, NY: Social Science Research Network. SSRN Scholarly Paper

[18] SDGs Index, (2018). Retrieve online from [http://sdgindex.org/]

[19] UNDP, (1997). Governance for Sustainable Human Development, A UNDP policy paper, pp 2-3

[20] UNDP, (2013a). Transparency International, "2015 and beyond: the governance solution for development", Working paper, 01 / 2013.

[21] UNDP, (2013b), Issue Brief: Integrating the Rule of Law in the Post 2015 Development Agenda (2013). Retrieve online from [http://www.undp.org/content/undp/en/home/ librarypage/democratic-governance/dg-publications/governance-and-the-post2015-development-framework/]

[22] UNDP HDR, (2018). Human Development Report, the technical details. Retrieve online from [http://hdr.undp.org/sites/default/files/hdr2016_technical_notes.pdf] (accessed on May 2018).

[23] UNESCWA, (2017). United Nations, Economic and Social Commission for Western Asia. Arab Region Progress in Sustainable Energy: Global Tracking Framework Regional Report. E/ESCWA/SDPD/2017/2.

[24] UN, (2001). UN Comm. Sustainable. Dev. 2001 E/CN.17/2001/19, Available online from [http://www.un.org/documents/ecosoc/docs/2001/e2001-29.pdf] (Accessed on May 2018) 
[25] UN, (2016). Sustainable Development Goals. Retrieve online from [http://www.un.org/ sustainabledevelopment/news/communications-material/] (Accessed on May 2018)

[26] UNSDSN, (2016). Preliminary Sustainable Development Goal (SDG) Index and Dashboard. Retrieve online from http://unsdsn.org/wp-content/uploads/2016/02/160215Preliminary-SDG-Index-and-SDG-Dashboard-working-paper-for-consultation.pdf]

[27] WGI, (2018). The Worldwide Governance Indicators. Retrieve online from [http://info. worldbank.org/governance/wgi/\#hom]

[28] World Bank, (2011) "Conflict, Security, and Development", World Bank World Development Report, 2011, p. 65.

[29] World Bank, (2018a). Yemen Economic outlook. Retrieve online from [http://documents.worldbank.org/curated/en/722171523637393846/pdf/125265MEM-April2018-Yemen-EN.pdf]

[30] World Bank Data, (2018b). Retrieve online from [https://data.worldbank.org/indicator/ SP.POP.DPND.YG?end=2016\&locations=XD-XM-XO-XN\&start=1977] (accessed on March,2019).

[31] World bank Yemen, (2018c). The world bank in Yemen. Retrieve online from [http: //www.worldbank.org/en/country/yemen/overview] (accessed on May,2018) 